\title{
Design and applications of miniaturized, portable LED based colorimeter
}

\author{
Tomas Drevinskas ${ }^{1,2}$, \\ Audrius Maruška ${ }^{1 *}$, \\ Eimantas Gladkauskas ${ }^{1,3}$, \\ Laimutis Telksnys ${ }^{2,4}$, \\ Valdas Girdauskas ${ }^{5}$, \\ Jelena Gorbatsova ${ }^{6}$, \\ Mihkel Kaljurand ${ }^{6,1}$, \\ Ona Ragažinskiené ${ }^{7}$
}

${ }^{1}$ Instrumental Analysis Open Access Centre, Faculty of Natural Sciences,

Vytautas Magnus University,

Vileikos St. 8, 44404 Kaunas, Lithuania

${ }^{2}$ Department of Systems' Analysis,

Faculty of Informatics,

Vytautas Magnus University,

Vileikos St. 8, 44404 Kaunas, Lithuania

${ }^{3}$ Department of Biotechnology,

Faculty of Engineering,

Lund University, Box 118,

SE-221 00 Lund, Sweden

${ }^{4}$ Institute of Data Science and Digital Technologies,

Vilnius University,

Goštauto St. 12, 01108 Vilnius, Lithuania

${ }^{5}$ Department of Physics,

Faculty of Natural Sciences,

Vytautas Magnus University,

Vileikos St. 8, 44404 Kaunas, Lithuania

${ }^{6}$ Department of Chemistry,

Faculty of Sciences,

Tallinn University of Technology,

Akadeemia tee 15, 12618 Tallinn, Estonia

${ }^{7}$ Sector of Medicinal Plants,

Botanical Garden of Vytautas Magnus University,

Ž. E. Žilibero St. 6, 46324 Kaunas, Lithuania
Portable and autonomous analytical instrumentation is becoming more important. Portable instrumentation can be designed via the miniaturization approach and this is a challenging task due to: (i) the limited battery power supply, (ii) a low number of mechanical and moving parts allowed in the design and (iii) susceptibility to changing environment and temperature fluctuations. In this work we describe the design of a light emitting diode (LED) based 3D printed miniaturized colorimeter (dimensions: $5 \mathrm{~cm} \times 4 \mathrm{~cm} \times 4.5 \mathrm{~cm}$ (length, width, height), weight less than $56 \mathrm{~g}$ ). The colorimeter was optimized for determination of the total phenolic compound content, the total flavonoid content and radical scavenging activity. The designed instrument provides comparable results to those of a conventional desktop spectrophotometer existing on the market. The designed LED based miniaturized colorimeter has wireless communication capability. This work demonstrates that this instrument can be applied investigating real samples.

Keywords: colorimetry, portable, LED, total phenolic compound content, total flavonoid content, radical scavenging activity

${ }^{*}$ Corresponding author. Email: audrius.maruska@vdu.lt 


\section{INTRODUCTION}

Analytical procedures of today are performed on the site (in situ) more often [1, 2]. This tendency is observed due to the main trend of miniaturization and integration applied in contemporary chemical analysis. Miniaturized and field portable instrumentation can help developing new methodologies and can help finding new types of applications [3, 4. Before working with new applications and innovative procedures, existing protocols should be implemented for the determination of compounds of interest in newly designed instrumentation.

The analysis that can be performed in situ provides several advantages: (i) reduces analysis errors due to the fact that sample transportation is not needed, and chemical degradation is avoided, and (ii) reduces the duration of the total analytical process [5]. Several chemical analyftical techniques have been applied, or are being developed for field-portable or autonomous applications: (i) liquid chromatography [6, 五, (ii) capillary electrophoresis [8-11], (iii) digital microfluidics [12] and (iv) electrochemical analysis [13]. Designing portable or autonomous instruments can be problematic due to the following reasons: (i) such instrumentation has the limited battery power supply, (ii) a low number of mechanical and moving parts must be used in the design, and (iii) such instrumentation is susceptible to changing environment and especially temperature fluctuations [10, 14].

One of the main interests of portable analytical applications is the environmental and phytochemical analysis. As it was demonstrated in the previous work, some compounds of interest start degrading immediately after the sampling procedure of the medicinal plant. Hence fresh material contained up to 4 times higher concentration of oenothein B compared to dried plant material [15]. Special data analysis methods, such as machine learning, or artificial intelligence methods applied in phytochemical investigations could be more efficiently utilized using portable, automated or autonomous instrumentation [16-19].

Colorimetry and spectrophotometry are widely used in analytical sciences [20]. Such techniques can be applied investigating specific compounds and determining special classes of chemical substances such as phenolic compounds, flavonoids, tannins, enzymatic activities, sonoporation and electroporation efficiency [15, 21-23]. Different works related to designing miniaturized light absorbance, or fluorescence detectors, are mainly focused on the light source instead of the light sensors [24-27]. Currently, miniaturized integrated circuits provide light sensing alternatives with digital output/data capabilities [28]. Several colorimetry approaches using a TCS3200 digital light sensor have been tested and released as open-source Arduino project [29]. Such design approaches can be applied developing new and miniaturized analytical instrumentation. Portable instrumentation would help solving the immediate degradation and postponed analysis problem.

The aim of this work was to design a miniaturized LED (light emitting diode) based portable colorimeter and to apply it for determination of total content of phenolic compounds, total content of flavonoids, and to measure radical scavenging activity with a perspective of using it in autonomous instrumentation in the future.

\section{EXPERIMENTAL}

\section{Chemicals}

Methanol (MeOH) (99.9\%), acetonitrile (ACN) (99.9\%), 2,2-diphenyl-1-picrylhydrazyl (DPPH), Folin-Ciocalceau reagent $2 \mathrm{~N}$ and rutin (95\%) were purchased from Sigma-Aldrich (Germany). Hexamethylenetetramine and aluminum chloride (99\%) were from Alfa Aesar. Sodium hydroxide (99.0\%) was purchased from Reachem (Slovakia). Bidistilled water was produced in the laboratory using a Fistreem Cyclon bidistillator (UK). Sodium carbonate trihydrate (99\%) was from ReaChem (Slovakia).

\section{Miniaturized colorimeter}

During the development of the instrument 3 models were made (Fig. 1). The first model was equipped with a LED of a single wavelength and wired (USB cable) connectivity, the second model was upgraded with 3 different colour LEDs, and the third model, together with the above-mentioned upgrades, had a possibility of wireless communication using an NRF24L01+ wireless transmitter (Nordic Semiconductor, Norway) [10]. 


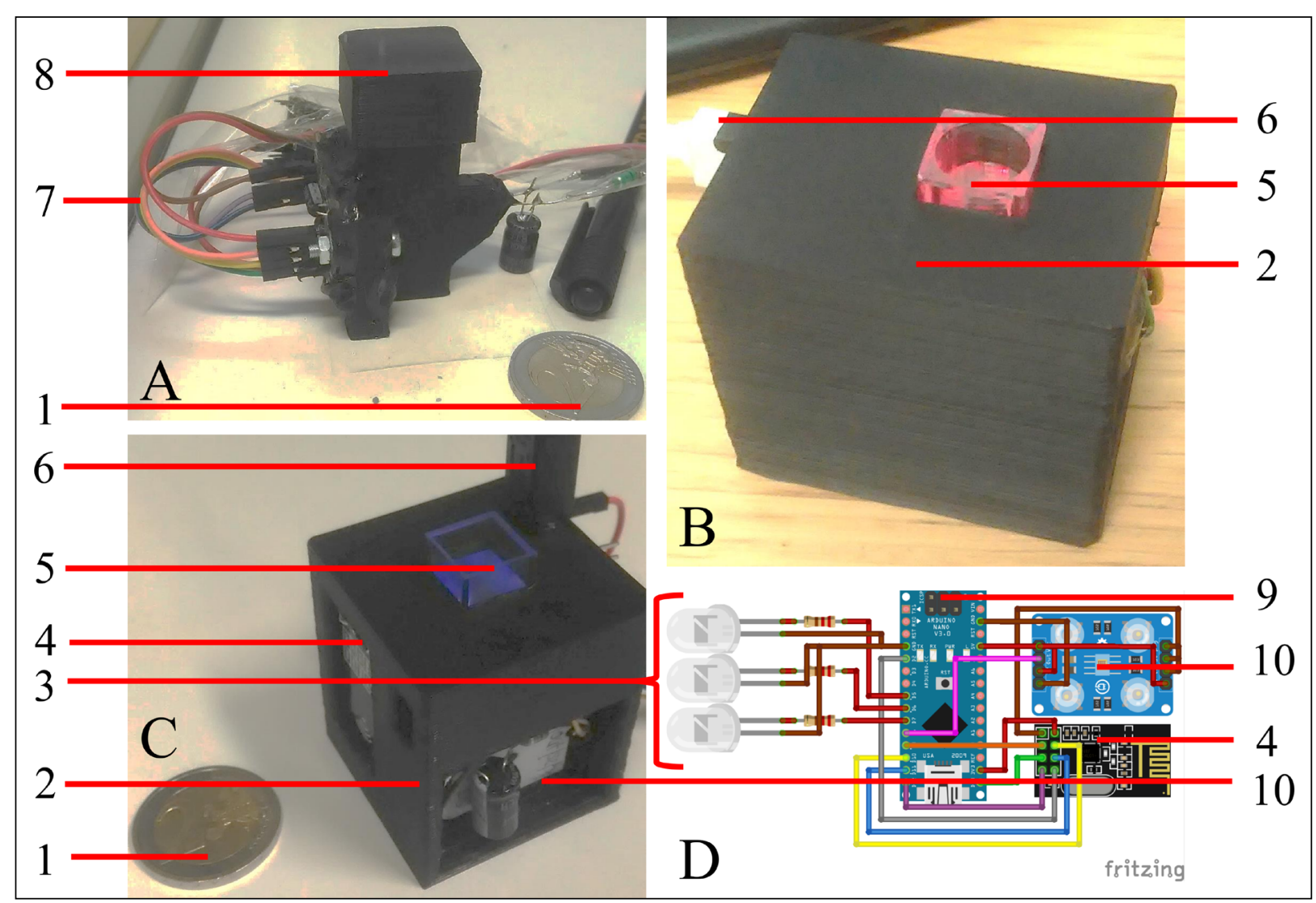

Fig. 1. Representation of the designed miniaturized colorimeters: (A) the 1st model with a single LED and wired communication, (B) the 2nd model with 3 LEDs and wired communication, (C) the 3rd model with 3 LEDs and wireless communication capability, (D) a wiring diagram of the designed instrument (drawn using Fritzing); (1) a two-euro coin for scale comparison, (2) a 3D printed frame, (3) LEDs, (4) an NRF24L01+ wireless communication module, (5) a cuvette with the sample, (6) a USB wire, (7) communication wires, (8) a cover, (9) an Arduino Nano microcontroller board, (10) a TCS3200 light sensor module

A TCS3200 light-to-frequency sensor (ams AG, Austria) was used as the main light measuring module. An Arduino Nano clone (Arduino, Italy) (working at $12 \mathrm{MHz}$ frequency) was used as the interface connecting a light sensor, a communication module and a power supply (purchased from the local store). The LEDs (red $650 \mathrm{~nm}$, green $520 \mathrm{~nm}$ and blue $470 \mathrm{~nm}$ (Vishay Semiconductors, USA)) were purchased from the local store. A miniaturized colorimeter frame was $3 \mathrm{D}$ printed from ABS plastic using a PrintrBot 3D printer (PrintrBot, USA). In the 1st model (Fig. 1 A) all electronic modules were placed outside the frame, that holds the cuvette, and the LED was sealed using black hot glue. In the frames of the 2 nd and 3rd models special positions were printed, so that the Arduino Nano microcontroller, the TCS3200 light sensor module, the NRF24L01+ wireless communication module and the wires would fit inside the 3D printed miniaturized colorimeter frame. The 2nd model (with USB communication capability) was supplied using $5 \mathrm{~V}$ from the USB wire and for the power supply of the 3rd model the $5 \mathrm{~V}$ external portable li-ion power bank was used. The dimensions of the instrument were $5 \times 4 \times 4.5 \mathrm{~cm}$ (length, width, height) and it weighted less than $56 \mathrm{~g}$.

The software used for signal acquisition and processing in the work was originally developed for capillary electrophoresis data acquisition and analysis, but in this work it was modified and applied for colorimetric measurements [30- 32 ].

Since the TCS3200 light sensor provides a linear value of the frequency corresponding to the light intensity at the output pin, the following equation (1), that complies with the Beer-Lambert law, was used to calculate the absorbance:

$$
A=\log _{10}\left(\frac{f_{z}}{f}\right) .
$$

Here $A$ is the absorbance, $f_{z}$ is the output frequency $(\mathrm{Hz})$ of the sensor at auto-zero conditions, 
$f$ is the output frequency $(\mathrm{Hz})$ when the sample is measured.

\section{Sample preparation}

The stock solution of calibration standards was prepared dissolving $20 \mathrm{mg}$ of rutin as a radical scavenging phenolic compound of flavonoid class into $20 \mathrm{ml}$ of a $75 \% \mathrm{MeOH} /$ water mixture. Before use, the stock solution was diluted using the $75 \% \mathrm{MeOH} /$ water mixture so that needed concentration solutions within the range of $0.01-1.00 \mathrm{mg} / \mathrm{ml}$ were obtained.

The following plants, based on the previous results, that were cultivated in Vytautas Magnus University Kaunas Botanical Garden, Lithuania, were selected as the model samples for the investigation: Saturea montana L. (S. montana), Chamaemelum nobile L. (Ch. nobile), Perilla frutescens $\mathrm{L}$. Britton. (P. frutescens), Agastache foeniculum (Pursh) Kuntze (A. foeniculum), Origanum vulgare L. (O. vulgare), Mentha piperita L. (M. piperita), Geranium macrorrhizum L. (G. macrorrhizum), Melissa officinalis L. (M. officinalis), Angelica archangelica L. (A. archangelica aerial part), $A n-$ gelica archangelica L. (A. archangelica roots), Thymus vulgaris L. (T. vulgaris), Hyssopus officinalis L. (H. officinalis), Nepeta cataria L. (N. cataria), Echinacea purpurea L. Moench. (E. purpurea), Salvia officinalis L. (S. officinalis) and Desmodium canadence L. DC. (D. canadence) [16, 17]. The extracts of the selected model plants were prepared following the previously published procedure: $0.5 \mathrm{~g}$ of the plant material was ground and the powder was extracted with $10 \mathrm{ml}$ of an extrahent ( $40 \%$ ethanol-water mixture). The extraction was performed for $24 \mathrm{~h}$ in an orbital shaker at 250 revolutions per minute, at ca. $+20^{\circ} \mathrm{C}$ ambient temperature. The samples were filtered using a paper filter.

Homemade wines were used as the model samples for investigation. The wines were produced following a classical wine production procedure [33]. Strawberries Fragaria $\times$ ananassa Duchesne (cultivar 'Honeoye') and grapes Vitis vinifera L. (cultivar 'Marechal Foch') were picked from the local garden and washed to remove contaminants like soil or dust. Neither special agents nor boiling water were added to kill wild yeast. The wild yeast method was picked due to their low tolerance to alcohol $(\sim 13 \%)$ to control the maximum amount of alcohol in wine. Berries were mashed and ground to release juice, a little amount of sugar was added to support and increase growth of wild yeast. After grinding, the juice together with peels were transferred to the glass jar. A small amount of water from local spring was added to the mixture. For the next few days, the jar was covered with a cloth lid to support gas exchange and to prevent insects entering wine. During the first day wine was mixed every several hours to increase the mass transfer and the growth of yeast. After several days when a rapid bubbling stopped (it was caused by yeast releasing carbon dioxide as subproduct), wine was strained off to remove peels of berries and to remove all sediment that was formed during rapid fermentation. After straining, wine was poured to a clean glass jar with an airlock mechanism on top, to remove $\mathrm{CO}_{2}$ and to prevent oxygen entering the jar. Wine was aging for 6 months, after that it was poured to glass bottles. To prevent any contamination a clean and sterile equipment was used. Before colorimetric procedures, the samples were filtered using a paper filter.

\section{Colorimetric procedures}

The procedures were performed using the designed instrument and for comparative reasons a Milton Roy Spectronic 1001 (USA) spectrophotometer was used. Spectrophotometric procedures were performed following previously published and optimized conditions [15-17, 34].

Determination of total phenolic compounds (TPC) TPC was determined using the Folin-Ciocalteu method. A sodium carbonate solution $(1.0 \mathrm{ml}$, $4 \%, \mathrm{pH} \mathrm{10)}$ was mixed with $0.033 \mathrm{ml}$ of the sample and then $0.033 \mathrm{ml}$ of the Folin-Ciocalteu reagent $(2 \mathrm{~N})$ was added. The reaction mixture was incubated for $30 \mathrm{~min}$ at $30^{\circ} \mathrm{C}$ and then the absorbance was measured at $760 \mathrm{~nm}$ using the Milton Roy Spectronic 1001 spectrophotometer and at $650 \mathrm{~nm}(20 \mathrm{~nm}$ bandwidth (Vishay Semiconductors, USA)). Rutin standard solutions (6 different levels of concentrations) were used for calibration in the range of 0.01 and $1.0 \mathrm{mg} / \mathrm{ml}$. Each measurement was repeated 3 times. The concentration of the samples was expressed as $\mathrm{mg} / \mathrm{ml}$ of rutin equivalents ( $\mathrm{mg} / \mathrm{ml} \mathrm{RE})$. 
Determination of total flavonoid content (TFC)

At the beginning, the stock solution was prepared from $60.0 \mathrm{ml} \mathrm{MeOH}, 3.0 \mathrm{ml}$ acetic acid (33\%), $12.0 \mathrm{ml}$ hexamethylenetetramine $(5 \%), 9.0 \mathrm{ml}$ aluminum chloride solution (10\%) and $60.0 \mathrm{ml}$ bidistilled water. The $0.04 \mathrm{ml}$ sample was added to the $0.96 \mathrm{ml}$ stock solution. After the incubation of $30 \mathrm{~min}$ at $+2^{\circ} \mathrm{C}$ the absorbance of the solutions was measured. Using the Milton Roy Spectronic 1001 spectrophotometer the absorbance was measured at $407 \mathrm{~nm}$ and, using the miniaturized colorimeter, the absorbance was measured at $470 \mathrm{~nm}$ (bandwidth $40 \mathrm{~nm}$ (Vishay Semiconductors, USA)). The calibration solutions of rutin standard ranged between 0.01 and $1.0 \mathrm{ml}$.

\section{Determination of radical scavenging activity (RSA)}

At the beginning, the $0.1 \mathrm{M}$ sodium acetate buffer $(250 \mathrm{ml})$ was prepared ( $\mathrm{pH} 5.5) . \mathrm{DPPH}(10 \mathrm{mg})$ was dissolved into $125 \mathrm{ml}$ of ACN and then $125 \mathrm{ml}$ of MEOH added. The obtained DPPH solution was mixed with the acetate buffer. The absorbance of such solution at $515 \mathrm{~nm}$ was 0.6 . The investigated sample $(0.025 \mathrm{ml})$ was added to the $1.0 \mathrm{ml}$ $\mathrm{DPPH}$ reagent, and after incubation of $15 \mathrm{~min}$ at $30^{\circ} \mathrm{C}$, the absorbance was measured at $515 \mathrm{~nm}$ with the Milton Roy Spectronic 1001 spectrophotometer and at $520 \mathrm{~nm}$ with the miniaturized colorimeter (bandwidth $40 \mathrm{~nm}$ (Vishay Semiconductors, USA)).

\section{RESULTS AND DISCUSSION}

\section{Optimization of instrumental design}

At the beginning, the intensity of the LED had to be adjusted. The LEDs were switched on or off using the digital output of the Arduino microcontroller board. The Arduino board provides $5 \mathrm{~V}$ output and this voltage was too high for a typical LED, therefore resistors were added in series with each LED. In order to find out what resistors have to be added in series, a series potentiometer (instead of a series resistor) was used. A potentiometer was regulated increasing or decreasing the resistance and at the same time measuring the output frequency and current in milliamperes that passes through the LED with a digital potentiometer. It was found that the frequency output at sensor saturation light levels was approximately $150 \mathrm{kHz}$. In the datasheet of the TCS3200 light sensor it is described that the minimum frequency at saturation light levels is $100 \mathrm{kHz}$. Selecting a resistor, it was decided to use the resistance of a series (to the LED) resistor that would provide the frequency output of the TCS3200 sensor slightly lower than $100 \mathrm{kHz}$. The limiting factor was the current that should not exceed $20 \mathrm{~mA}$, that is the typical working current of the LED. Higher current induces excessive heating that can cause instability in the light source (LED).

After the adequate resistors for LEDs were selected, it was decided to program the required algorithm into the Arduino microcontroller board. The Lambert-Beer law can be expressed by Eq. (2):

$$
A=\log _{10}\left(\frac{T_{0}}{T}\right) .
$$

Here $A$ is the absorbance, $T_{0}$ is the transmittance (\%) when the sample does not absorb the light, $T$ is the transmittance (\%) when the sample is measured. The TCS3200 sensor provides a frequency value at the output that is linearly proportional to the light intensity, or the transmittance. In order to calculate the absorbance, the resolution of the transmittance that correspond, to $1 \mathrm{~Hz}$ of the frequency should be found following Eq. (3):

$$
T_{r}=\frac{100}{f_{z}} .
$$

Here $T_{r}$ is the resolution of the transmittance that corresponds to $1 \mathrm{~Hz}$ of the frequency, $f_{z}$ is the output frequency $(\mathrm{Hz})$ of the sensor when the sample does not absorb the light, the value of 100 is the percentage $\left(T_{0}\right)$. The transmittance of the sample can be calculated following Eq. (4):

$$
T=\frac{T_{r}}{f} .
$$

Here $T$ is the transmittance (\%) when the sample is measured, $f$ is the frequency $(\mathrm{Hz})$ when the sample is measured. Having all the calculated values, the absorbance can be calculated following Eq. (5):

$$
A=\log _{10}\left(\frac{100 \times f_{z}}{100 \times f}\right) .
$$

Here $A$ is the absorbance, $f_{z}$ is the output frequency $(\mathrm{Hz})$ of the sensor when the sample does not absorb the light, $f$ is the frequency $(\mathrm{Hz})$ when the light absorbing sample is measured. The values of $100 \mathrm{can}$ 
be cancelled out modifying this equation to Eq. (1). The algorithm performing the mathematical equation (1) was programmed into the Arduino Nano microcontroller and the whole measurement sequence is represented in Fig. 2 .

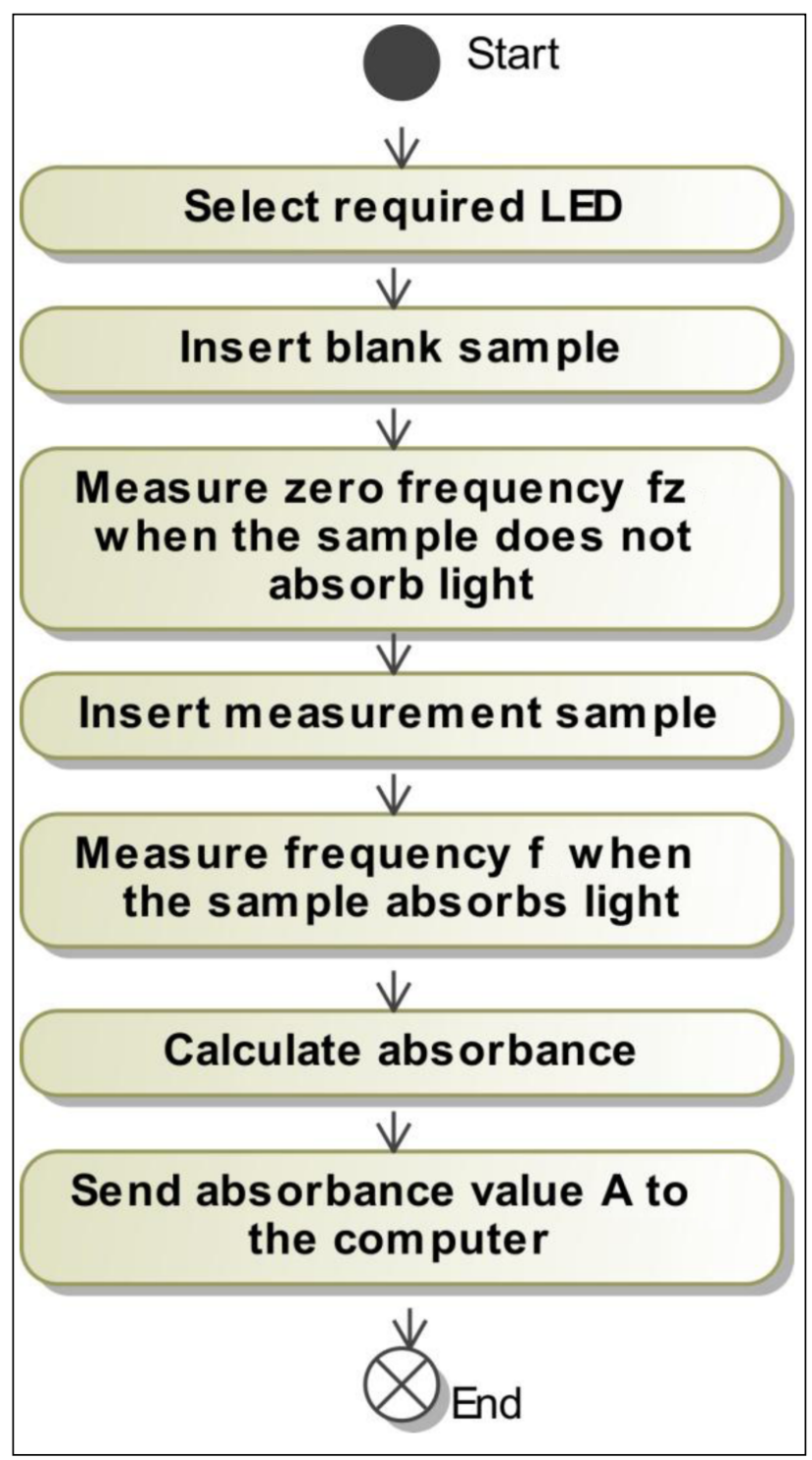

Fig. 2. The algorithm of the absorbance measurement of the sample

During the absorbance measurement procedure with the miniaturized colorimeter, specific functions are performed: (i) the required LED is selected for operation, red $(650 \mathrm{~nm})$, green $(520 \mathrm{~nm})$ or blue $(470 \mathrm{~nm})$; (ii) the blank sample, that does not absorb the light, is inserted into the colorimeter; (iii) the zero absorbance frequency $f_{z}$ is measured and stored inside the memory of the microcontroller; (iv) the blank sample is taken out and the measurement sample is inserted into the colorimeter; (v) the frequency $f$ is measured; (vi) the absorbance is calculated following Eq. (1); (vii) the value of the absorbance $\mathrm{A}$ is sent to the computer. All calculations and measurement are performed automatically and the insertion and removal of the samples are done manually.

\section{Optimization and application of colorimetric procedures}

In the beginning of application of colorimetric procedures, it was decided to test the miniaturized colorimeter for determination of TPC. Simultaneously the samples were tested using the Milton Roy spectrophotometer. The calibration equations were obtained: (i) the miniaturized colorimeter indicated the calibration equation $y=1.036 x+0.018$ and the regression coefficient (for linearity) was $\mathrm{R}^{2}=0.994$; (ii) the Milton Roy spectrophotometer indicated the equation $y=1.155 x+0.046$ and the regression coefficient was $\mathrm{R}^{2}=0.996$. Repeatability was investigated and the relative standard deviation (RSD) calculated did not exceed $5 \%$ for both instruments. It was decided to test the miniaturized colorimeter and the TPC procedure with the same dataset of antivirally active medicinal plant extracts, that were investigated using the Milton Roy spectrophotometer in the previous works [16, 17]. In the previous work it was found that TPC is one of the main attributes that provide information on antiviral and cytotoxic characteristics in the extracts. The data indicated only minor differences (Fig. 3). TPC did not statistically differ in all the investigated solutions except the extract of $A$. archangelica root, where the miniaturized colorimeter indicated a slightly higher content: $0.75 \pm 0.04$ (Milton Roy spectrophotometer) and $0.91 \pm 0.05$ (miniaturized spectrophotometer) $\mathrm{mg} / \mathrm{ml} \mathrm{RE}$. Using the developed miniaturized colorimeter, the highest concentrations of phenolic compounds were determined in O. vulgare (7.18 \pm 0.36$)$, G. macrorrhizum (7.65 \pm 0.38$)$, M. officinalis $(7.75 \pm 0.39)$ and $D$. canadence extracts $(7.06 \pm 0.35 \mathrm{mg} / \mathrm{ml} \mathrm{RE})$. The lowest concentrations of TPC were determined in A. archangelica root $(0.91 \pm 0.04)$ and $N$. Cataria $(1.63 \pm 0.08) \mathrm{mg} / \mathrm{ml} \mathrm{RE}$ extracts. Other extracts possessed intermediate amounts of TPC.

It was clarified that the designed miniaturized spectrophotometer could be applied for the TPC 


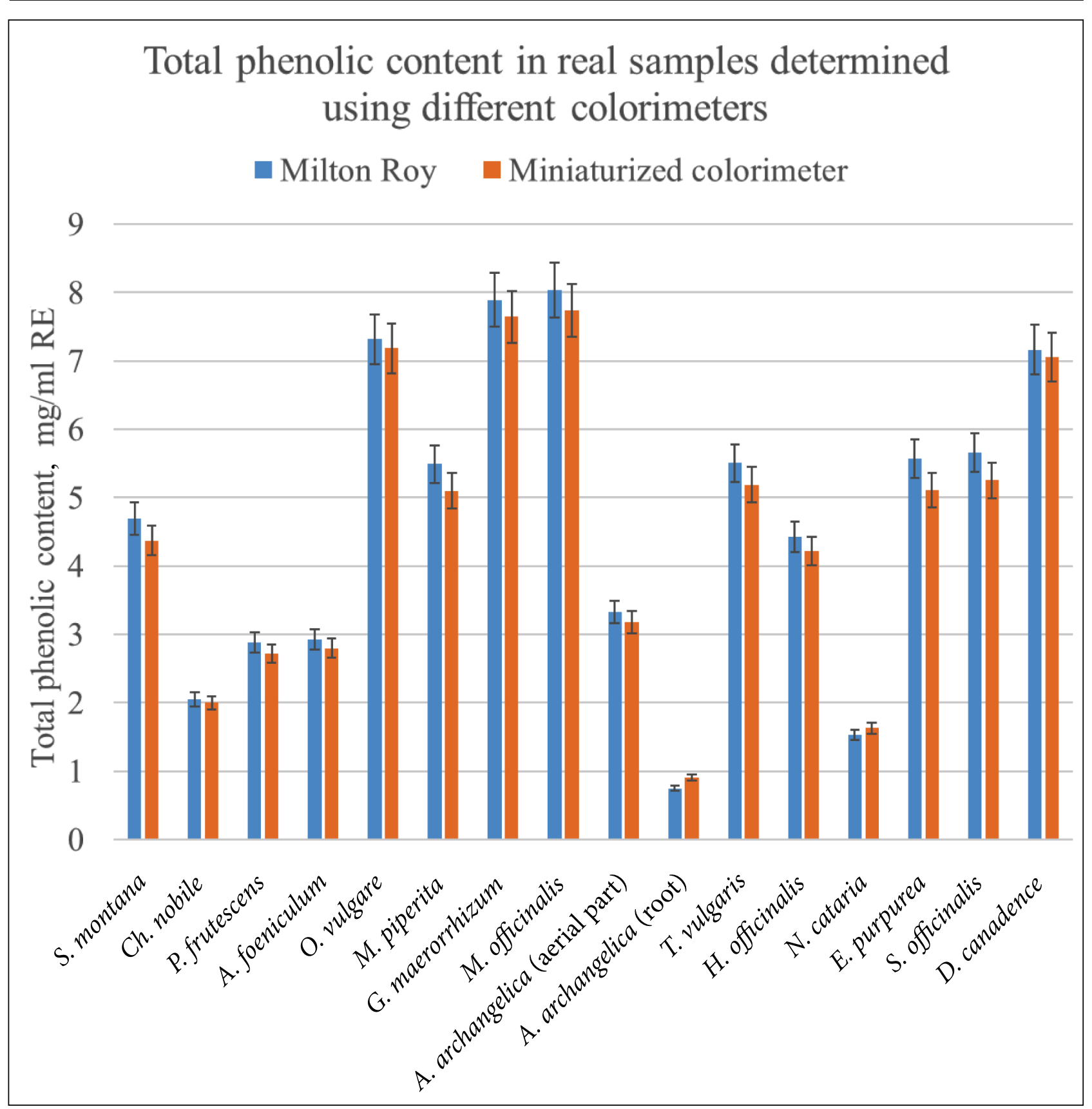

Fig. 3. Total phenolic content in different plant extracts determined using different colorimeters

could procedure, therefore it was proceeded for the next protocol - the determination of TFC.

Initially, using the 1st model, a near UV LED (395 nm) was inserted into the colorimeter. The instrument was tested for the TFC procedure. It was noticed that when using plastic cuvettes the Milton Roy spectrophotometer showed superior linearity $\left(\mathrm{R}^{2}=0.996\right)$ over the miniaturized colorimeter $\left(\mathrm{R}^{2}=0.861\right)$. Such findings were not observed with a quartz cuvette. The Milton Roy spectrophotometer showed $\mathrm{R}^{2} 0.998$ and the miniaturized colorimeter showed $\mathrm{R}^{2} 0.999$. This is due to the fact that a plastic cuvette absorbs near UV light. For this work it was decided to search for another alternative and use plastic cuvettes instead of quartz, which is considered expensive and should be used carefully in field portable applications. In the $2 \mathrm{nd}$ and 3 rd models a blue LED (470 $\mathrm{nm}$ ) was used as one of the light sources instead of near UV $395 \mathrm{~nm}$ LED. It was noticed that the miniaturized colorimeter provided an approximately 10 times lower response to the same concentration levels of rutin comparing it to the Milton Roy spectrophotometer. Fortunately, the miniaturized colorimeter 
indicated lower noise (0.0003) than the Milton Roy spectrophotometer $(0.0050)$ at the $0.5 \mathrm{mg} / \mathrm{ml}$ rutin concentration using the TFC procedure. It can be stated that the designed miniaturized colorimeter provided c.a. 16 times better signal to the noise ration than the Milton Roy spectrophotometer. This is due to the fact that LED as a light source provides higher intensity light than a deuterium lamp with diffraction grating in the Milton Roy spectrophotometer. In different analytical instrumentation, sophisticated signal smoothing algorithms are applied [11]. It was decided to apply signal smoothing for the signal of the miniaturized colorimeter. Moving average function with the window size of 8 was applied for the miniaturized colorimeter absorbance signal. This procedure reduced the noise approximately 3 times.

The instrument was calibrated in the range of 0.01 to $7.0 \mathrm{mg} / \mathrm{ml}$ rutin solutions. It was found that using the absorbance wavelength of $470 \mathrm{~nm}$ in the miniaturized colorimeter, the dynamic range was greatly increased: from $0.01-1.0$ to $0.01-7.0 \mathrm{mg} / \mathrm{ml}$. The linearity was found superior to the Milton Roy spectrophotometer: $\mathrm{R}^{2} 0.999$ for the miniaturized colorimeter (calibration curve: $y=0.1017 x+0.0151)$ and $\mathrm{R}^{2} 0.996$ for the Mil- ton Roy spectrophotometer (calibration curve: $y=0.9177 x-0.0446)$. Such instrument can be extremely useful investigating TFC of multiple samples that possess high and low levels of flavonoids. In this case, no or minor dilutions would be required.

Investigating radical scavenging activity with the DPPH reagent, the miniaturized colorimeter indicated the calibration curve $y=-0.646 x+0.582$ and the coefficient of determination was $\mathrm{R}^{2} 0.994$. The Milton Roy spectrophotometer indicated the calibration curve $y=-1.762 x+0.511$ and the coefficient of determination was $\mathrm{R}^{2} 0.995$. It was noticed that the response is different for different instruments, yet this can be explained by the fact that both instruments use different light sources, of different wavelengths and different bandwidths. Both instruments indicated a satisfactory linearity. The miniaturized colorimeter was found to be applicable for the determination of a higher range of concentrations: $0.01-0.75 \mathrm{mg} / \mathrm{ml} \mathrm{RE}$ (miniaturized colorimeter) and $0.01-0.30 \mathrm{mg} / \mathrm{ml} \mathrm{RE}$ (Milton Roy spectrophotometer).

The designed miniaturized colorimeter was applied for the determination of TPC, TFC and RSA of fermented strawberry wine and fermented grape wine (Fig. A).

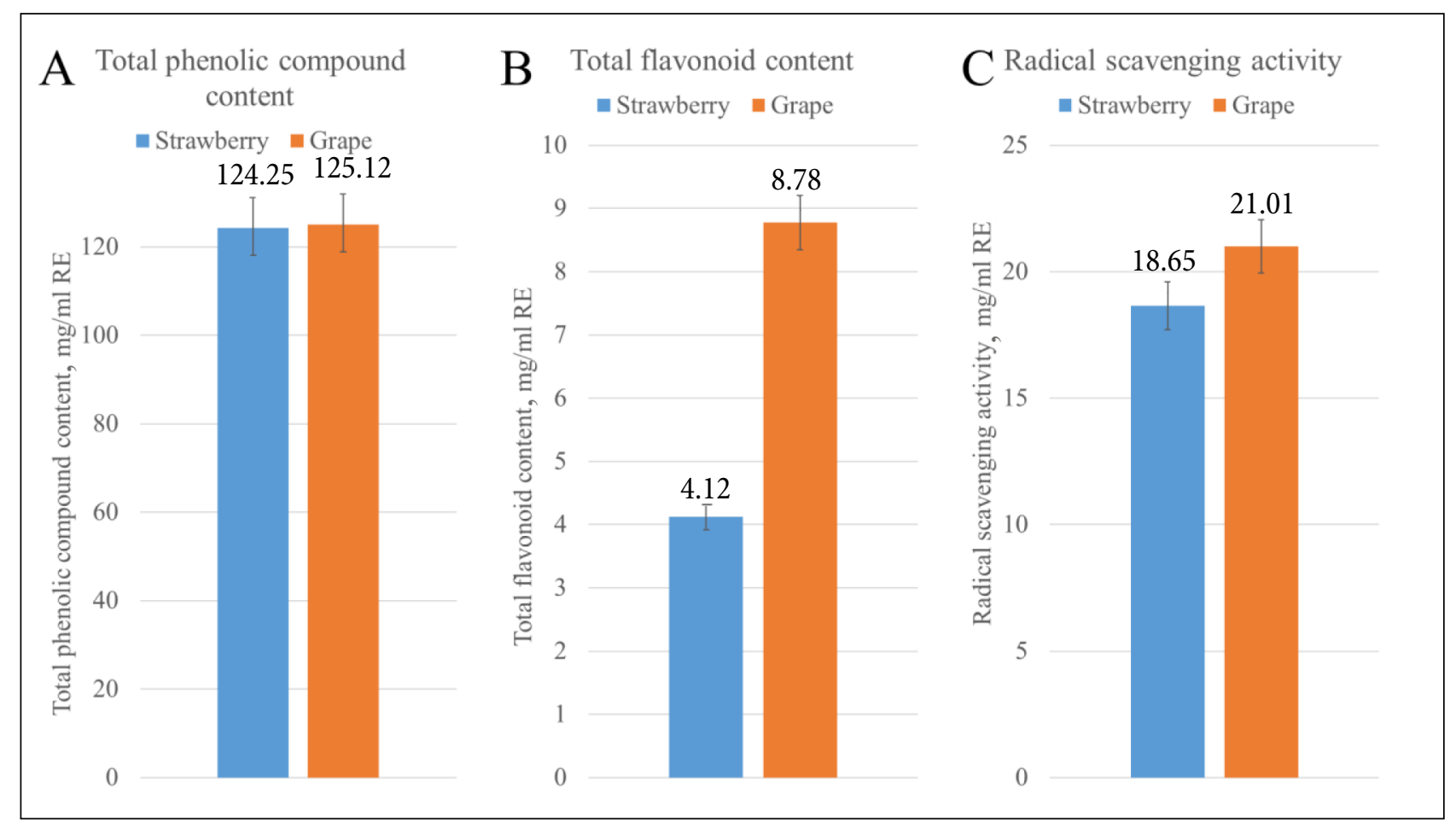

Fig. 4. Determination using miniaturized colorimeter and comparison of TPC, TFC and RSA in strawberry and grape wines 
It was found that the total phenolic content in strawberry and grape wines did not statistically differ $(125.1 \pm 3.13$ (in strawberry wine) vs $124.2 \pm 3.10$ (in grapefruit wine) $\mathrm{mg} / \mathrm{ml} \mathrm{RE}$ ). Approximately a 2 times higher concentration of flavonoids was found in grapefruit $(8.8 \pm 0.22 \mathrm{mg} / \mathrm{ml} \mathrm{RE})$ wine than in strawberry $(4.1 \pm 0.10 \mathrm{mg} / \mathrm{ml} \mathrm{RE})$ wine. A slightly higher radical scavenging activity was determined in grapefruit $(21.0 \pm 0.52 \mathrm{mg} / \mathrm{ml} \mathrm{RE})$ wine than in strawberry $(18.6 \pm 0.46 \mathrm{mg} / \mathrm{ml} \mathrm{RE})$ wine.

\section{CONCLUSIONS}

In this study: (i) a portable miniaturized colorimeter with a wireless data communication possibility was developed; (ii) the procedures of determination of (a) total phenolic compound content, (b) total flavonoid content and (c) radical scavenging activity were adapted and optimized for the designed miniaturized colorimeter; (iii) the highest concentrations of phenolic compounds were determined in antiviral plants $O$. vulgare $(7.18 \pm 0.36)$, G. macrorrhizum (7.65 \pm 0.38$)$, M. officinalis $(7.75 \pm 0.39)$ and $D$. canadence medicinal plant extracts $(7.06 \pm 0.35 \mathrm{mg} / \mathrm{ml} \mathrm{RE})$. The lowest concentrations of TPC were determined in A. archangelica root $(0.91 \pm 0.04)$ and $N$. cataria $(1.63 \pm 0.08 \mathrm{mg} / \mathrm{ml} \mathrm{RE})$ medicinal plant extracts; (iv) the samples of the investigated strawberry and grape wines showed that (a) higher total flavonoid content was observed in grape wine $(8.8 \pm 0.22 \mathrm{mg} / \mathrm{ml} \mathrm{RE})$ than in strawberry wine $(4.1 \pm 0.10 \mathrm{mg} / \mathrm{ml} \mathrm{RE})$, (b) higher radical scavenging activity was observed in grape wine $(21.0 \pm 0.52 \mathrm{mg} / \mathrm{ml} \mathrm{RE})$ than in strawberry wine $(18.6 \pm 0.46 \mathrm{mg} / \mathrm{ml} \mathrm{RE})$ and (c) similar content of phenolic compounds was found in both wines (in grape wine $125.1 \pm 3.13$ and in strawberry wine $124.2 \pm 3.10 \mathrm{mg} / \mathrm{ml} \mathrm{RE}$ ).

\section{ACKNOWLEDGEMENTS}

The authors dedicate this work to Prof. Slellan Hjertén, who celebrates his 90th birth anniversary this year. This research was funded by a grant (No. 09.3.3-LMT-K-712-02-0202) from the Research Council of Lithuania. The Milton Roy Spectronic 1001 spectrophotometer was a donation of the Alexander von Humboldt Foundation (Germany).

Received 23 August 2018 Accepted 18 September 2018

\section{References}

1. M. F. Mora, A. M. Stockton, P. A. Willis, Electrophoresis, 33, 2624 (2012).

2. M. L. Cable, S. M. Hörst, C. He, et al., Earth Planet. Sci. Lett., 403, 99 (2014).

3. Á. Ríos, M. Zougagh, M. Avila, Anal. Chim. Acta, 740, 1 (2012).

4. S. J. Trietsch, T. Hankemeier, H. J. van der Linden, Chemom. Intell. Lab. Syst., 108, 64 (2011).

5. C. D. M. Campos, J. A. F. Da Silva, RSC Adv., 3, 18216 (2013).

6. K. R. Elkin, J. Chromatogr. A, 1352, 38 (2014).

7. B. Yang, M. Zhang, T. Kanyanee, B. N. Stamos, P. K. Dasgupta, Anal. Chem., 86, 11554 (2014).

8. E.-G. Kobrin, H. Lees, M. Fomitšenko, P. Kubáň, M. Kaljurand, Electrophoresis, 35, 1165 (2014).

9. H. Becker, H. Muehlberger, W. Hoffmann, T. Clemens, R. Klemm, C. Gaertner, Microfluid. Biomems, Med. Microsystems VI, 6886, 8860 (2008).

10. T. Drevinskas, L. Telksnys, A. Maruška, J. Gorbatsova, M. Kaljurand, Electrophoresis (2018) https:// doi.org/10.1002/elps.201800132].

11. T. Drevinskas, L. Telksnys, A. Maruška, J. Gorbatsova, M. Kaljurand, Anal. Chem., 90, 6773 (2018).

12. J. Gorbatsova, M. Jaanus, M. Vaher, M. Kaljurand, Electrophoresis, 37, 472 (2016).

13. F. S. Felix, L. Angnes, Biosens. Bioelectron., 102, 470 (2018).

14. M. Kaljurand, Trends Environ. Anal. Chem., 1, e2 (2014).

15. V. Kaškonienė, M. Stankevičius, T. Drevinskas, et al., Phytochemistry, 115, 184 (2015).

16. T. Drevinskas, R. Mickienè, A. Maruška, et al., Anal. Methods, 10, 1875 (2018).

17. T. Drevinskas, R. Mickienè, A. Maruška, et al., Chemija, 29, 124 (2018).

18. M. Wesołowski, B. Suchacz, Anal. Bioanal. Chem., 371, 323 (2001).

19. C. Ruiz-Samblás, J. M. Cadenas, D. A. Pelta, L. Cuadros-Rodríguez, Anal. Bioanal. Chem., 406, 2591 (2014).

20. A. Khoddami, M. A. Wilkes, T. H. Roberts, Molecules, 18, 2328 (2013).

21. N. Tiso, J. Mikašauskaite, M. Stankevičius, et al., Toxicol. Environ. Chem., 98, 77 (2016).

22. B. Jakštys, P. Ruzgys, M. Tamošiūnas, S. Šatkauskas, J. Membr. Biol., 248, 857 (2015).

23. P. Ruzgys, M. Tamošiūnas, V. Lukinsone, S. Šatkauskas, J. Biomed. Opt., 22, 1 (2017).

24. P. K. Dasgupta, I. Y. Eom, K. J. Morris, J. Li, Anal. Chim. Acta, 500, 337 (2003).

25. Y. Zhao, Q. Li, X. M. Hu, D. F. Yang, Photonics Lasers Med., 2, 51 (2013).

26. X. Geng, D. Wu, Y. Guan, Talanta, 88, 463 (2012).

27. F. B. Yang, J. Z. Pan, T. Zhang, Q. Fang, Talanta, 78, 1155 (2009). 
28. Light Sensors - ams [https://ams.com/light-sensors].

29. Educational Colorimeter Kit - IO Rodeo https:// iorodeo.com/collections/open-source-colorimeter.

30. T. Drevinskas, M. Kaljurand, A. Maruška, Electrophoresis, 35, 2401 (2014).

31. T. Drevinskas, A. Maruška, V. Briedis, Electrophoresis, 36, 292 (2015).

32. T. Drevinskas, G. Naujokaityte, A. Maruška, et al., Carbohydr. Polym., 173, 269 (2017).

33. K. M. Herstein, T. C. Gregory, Chemistry and Technology of Wines and Liquors, D. Van Nostrand Company, Inc., New York (1938).

34. V. Kaškonienè, A. Maruška, I. Akun,eca, et al., Nat. Prod. Res., 30, 1373 (2016).
Tomas Drevinskas, Audrius Maruška, Eimantas Gladkauskas, Laimutis Telksnys, Valdas Girdauskas, Jelena Gorbatsova, Mihkel Kaljurand, Ona Ragažinskienè

\section{MINIATIŪRIZUOTO NEŠIOJAMOJO KOLORIMETRO SU ŠVIESTUKU KŪRIMAS IR PRITAIKYMAS}

Santrauka

Nešiojami ir autonominiai analitiniai instrumentai tampa vis svarbesni. Nešiojamą ịrangą galima sukurti, jei bus vadovaujamasi miniatiūrizacijos kriterijais. Procesas sudètingas dèl trijų priežasčių: tokioje įrangoje ribotas maitinimo šaltinis; galima naudoti tik ribotą kiekį mechaninių ir judančių detalių; tokią įrangą nesunkiai gali pažeisti besikeičianti aplinka ir temperatūra. Šiame darbe aprašytas 3D spausdintuvu atspausdintas kolorimetras su šviestuku (dimensijos: $5 \times 4 \times 4,5 \mathrm{~cm}$ (ilgis, plotis, aukštis), svoris mažesnis nei $56 \mathrm{~g}$ ). Kolorimetras optimizuotas taip, kad juo būtų galima nustatyti bendrą fenolinių junginių kiekį, bendrą flavonoidu kiekị ir bendrą radikalų surišimo aktyvumą. Sukurtu instrumentu gaunami rezultatai yra lygintini su gautais pritaikius rinkoje esantị spektrofotometrą. Taip pat miniatiūrizuotas kolorimetras su šviestuku turi ir bevielès komunikacijos galimybę. Pademonstruota, kad ši sukurtą kolorimetrą galima pritaikyti atliekant realių bandinių tyrimus. 